\title{
Quality of life in women with urinary incontinence
}

\author{
Cláudia Senra ${ }^{1 *}$, M. Graça Pereira ${ }^{2}$ \\ 'Psychology Master - University of Minho, School of Psychology, Braga, Portugal \\ ${ }^{2} \mathrm{PhD}$ - Associate Professor. University of Minho, School of Psychology, Braga, Portugal
}

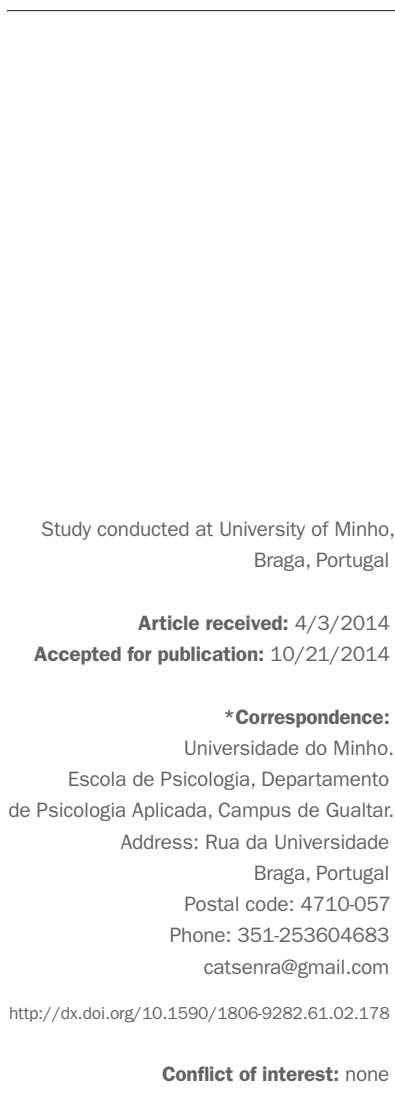

\section{SUMmarY}

The aim of this study is to examine the relationship among psychological, clinical and sociodemographic variables, and quality of life in women with urinary incontinence. The sample consisted of 80 women diagnosed with urinary incontinence (UI) followed in a Northern Central Hospital in Portugal. Participants answered the Incontinence Quality of Life (I-QOL); Satisfaction with Sexual Relationship Questionnaire (SSRQ); Hospital Anxiety and Depression Scales (HADS) and the Brief Cope. The results revealed that women with higher quality of life considered their symptoms of urine loss as mild or moderated compared to those with severe urine loss. The less severe urine loss was associated with greater sexual satisfaction and less use of religion and self-blame as coping strategies. In terms of coping, women who considered the loss of urine as severe expressed more feelings regarding UI. Stress urinary incontinence, high sexual satisfaction, and less use of denial, distraction, and religion as coping strategies, predicted higher quality of life. According to the results, UI has an impact on women's sexual satisfaction and quality of life. Therefore, intervention programs should target these women, including their partners, helping them to adjust to their condition and teaching effective coping strategies in order to improve their sexual satisfaction and quality of life.

Keywords: urinary incontinence, quality of life, sexual satisfaction, psychological morbidity, coping strategies.

\section{INTRODUCTION}

Voluntary control of the bladder is a prerequisite for the sense of normality, self-esteem and independence, ${ }^{1}$ which begins in childhood as something personal not socially talked about. Therefore, urine loss is a condition with a profound impact in social life, both for children and adults. ${ }^{2}$

According to the International Continence Society, the complaints related to involuntary urine loss is called urinary incontinence (UI), that may be stress urinary incontinence (SUI) associated with effort, sneeze or cough, urge urinary incontinence (UUI) associated with loss, accompanied or immediately preceded by urgency, and finally mixed urinary incontinence (MUI) that occurs due to urgency, effort, sneezing or coughing. ${ }^{3}$ Although UI is not considered a severe physical disease and does not affect people's life directly, it is a common condition and is linked to numerous psychological and social and economical problems. ${ }^{4,5}$ The leakage of urine involves several repercussions in quality of life of adult women, ${ }^{6,7}$ in their emotional state and in sexual intercourse. ${ }^{8,9}$ Taking in consideration the fact that $\mathrm{UI}$ is related to areas of the body hidden by clothing and sexuality, it is still a taboo in Western societies, associated with myths and social restrictions. ${ }^{10}$ In fact, women often choose not to leave their home for fear and shame of losing urine in public, feeling wet and smelling, not finding a bathroom when they need to change clothes or their protective pad. As a result, several women with UI, avoid going to parties, long trips, attending church and participating in physical activities such as walking, running, playing and dancing. $5,8,9$

According to the WHOQOL, ${ }^{11}$ quality of life depends on the subjective perception of the UI, and its treatment at social, physical and mental levels. Temml et al. ${ }^{12}$ found that $66 \%$ of women reported that their quality of life was affected by UI. In general, women consider that UI has a greater impact on physical and social activities, trust and selfperception ${ }^{13}$ and have a smaller impact on daily activities. $^{14}$ 
Sexuality plays a vital role ${ }^{15}$ and is a complex issue, strongly modulated by psychosocial factors. ${ }^{16} \mathrm{Temml}$ et al. ${ }^{12}$ found that $25 \%$ of women reported that the UI contributed to a decrease in sexual life. Sexual dissatisfaction in women resulted in a decreased personal and marital quality of life. ${ }^{17}$

In the study of Lagro-Janssen et al. ${ }^{18}$ women reported that the UI was not a problem that threatened their lives or limited their activities, but disturbed their lifestyles and especially their functioning and psychological well-being. Of a total of 82 women with UI, $26 \%$ had depressive symptoms, while $29 \%$ had anxiety symptoms. ${ }^{19}$ Yip and Cardo$\mathrm{zo}^{20}$ reported that there is a probability of psychological morbidity due to the impact of UI on quality of life. For Melville et al. ${ }^{21}$ and Vigod and Stewart, ${ }^{22}$ major depression and comorbidity significantly affect the quality of life in women with UI. Stach-Lempinen et al. ${ }^{19}$ found that women with UI showed decreased quality of life and reported more symptoms of depression.

Coping strategies are very important to maintain one's identity and perceived competence, ${ }^{23}$ since UI is often associated with lack of self-control. ${ }^{24}$ Studies found that the following coping strategies: active coping, ${ }^{25}$ acceptance of the disease, being optimistic, ${ }^{26}$ expression of feelings, ${ }^{27}$ positive religious coping, ${ }^{28}$ were associated with better quality of life. ${ }^{29}$ Other studies revealed that behavioral disengagement, ${ }^{25}$ self-blame, ${ }^{30}$ high distraction, ${ }^{26}$ and negative religious coping, such as a pessimistic view of the world and spiritual discomfort ${ }^{28}$ were associated with worse quality of life, in patients with chronic diseases.

In Portugal, psychological studies that address the impact of urinary incontinence on quality of life are scarce. Based on the model of Liveneh on the adaptation and adjustment to a chronic disease or condition, ${ }^{31,32}$ psychological morbidity (reaction to the problem), sexual satisfaction and coping strategies (contextual variables) were analyzed as predictors of quality of life. Also, differences in sexual satisfaction, psychological morbidity and coping strategies, according to the severity of urine loss, were also analyzed.

\section{Methods}

Eighty women diagnosed with UI were followed in the Physical and Rehabilitation Medicine Unit in a major Hospital in the North of Portugal. Inclusion criteria included: being an adult woman diagnosed with UI and having sexual activity. Participation was voluntary.

\section{Participants}

Woman's age ranged from 27 to 80 years old, with a mean age of 45.59 years old $(S D=12.04) .71 .3 \%$ of women had only four years of school education, $13.8 \%$ had ten years of education and $13.8 \%$ a university degree. Regarding the type of UI, $75 \%$ presented SUI, $17.5 \%$, UUI and $7.5 \%$ MUI. $11.3 \%$ had surgery for UI.

\section{Measurements}

- Incontinence Quality of Life (I-QOL) consists of 22 items grouped into three domains which are: avoidance and limiting behaviors with eight items, psychosocial impacts with nine items, and social embarrassment with five items. Higher scores represent better quality of life. In the current study, the Cronbach alpha was .95 .

- Satisfaction with Sexual Relationship Questionnaire $(\mathrm{SSRQ})^{34,35}$ consists of 14 items and two domains: sexual relationship (eight items) and confidence (six items). The confidence domain has two subscales: self-esteem (four items) and overall relationship (two items). A high score indicates higher sexual satisfaction. In the current study, Cronbach's alpha was .97.

- Hospital Anxiety and Depression Scales (HADS): ${ }^{36,37}$ consists of two subscales, one measuring anxiety, with seven items, and one measuring depression, with seven items, which are scored separately. A high score indicates greater psychological morbidity. A score between 0 and 7 is "normal", between 8 and 10 is "mild", between 11 and 14 is "moderate" and between 15 and 21 is "severe". ${ }^{38}$ In the current study, Cronbach's alpha was .78 for anxiety and .67 for depression.

- Brief Cope $e^{39,40}$ consists of 28 items and fourteen domains: active coping, planning, positive reinterpretation, acceptance, humor, religion, seeking of emotional support, seeking of instrumental support, distraction, denial, expression of feelings, substance use, behavioral disengagement and self-blame. These subscales, each one with two items, are separately scored. In the current study, Cronbach's alpha ranged from .51 to .97 , as in the original version. Two of the subscales were removed: planning and seeking instrumental support, due to low internal consistency (alpha below .70). ${ }^{41}$

\section{Data analyses}

To test differences between the groups, the Mann-Whitney tests with Bonferroni correction were used. To find the best predictors of quality of life, hierarchical regression (Enter method) was performed. To find the best coping strategies that predicted quality of life, a multiple linear regression was used with the coping subscales that were highly correlated with quality of life introduced as predictors. 


\section{RESULTS}

Differences between sexual satisfaction, psychological morbidity and coping according to the severity of urine loss

The results revealed significant differences on quality of life between women who reported loss of urine as mild versus moderate, mild versus severe and moderated versus severe $\left(\chi^{2}(2)=29.61, \mathrm{p}^{<.001)}\right.$. Women with a higher quality of life were those who reported their symptoms of urine loss as mild or moderated.

The results revealed significant differences in sexual satisfaction between women who reported loss of urine as mild versus severe $\left(\chi^{2}(2)=7.38, p^{<} .05\right)$, use of religion $\left(\chi^{2}\right.$ $\left.(2)=7.67, p^{<} .05\right)$ and self-blame $\left(\chi^{2}(2)=6.81, p^{<} .05\right)$. So, the less severe symptoms of urine loss, the greater was sexual satisfaction, as well as less use of religion and self-blame as coping strategies. Differences were also found on expression of feelings in women who reported loss of urine as moderate versus severe $\left(\chi^{2}(2)=7.57, p^{<} .05\right)$. Women who reported loss of urine as severe used more expression of feelings to deal with the UI. Finally, there were differences between women who reported loss of urine as mild versus severe as well as moderated versus severe on the use of de$\operatorname{nial}\left(\chi^{2}(2)=14.64, \mathrm{p}<.01\right)$ and the use of distraction as coping strategies $\left(\chi^{2}(2)=15.60, \mathrm{p}<.001\right)$. Therefore, women who perceive the symptoms of urinary loss as severe use more denial and distraction as coping strategies.
There were no significant differences in the remaining variables (Table 1 ).

Predictors of quality of life

Age, type of UI, psychological morbidity and sexual satisfaction predicted quality of life $F(5,74)=14.33, \mathrm{p}<.001$, and the model explained $49 \%$ of the variance. Women with UI who were more satisfied with their sexual relationships showed a better quality of life $(\beta=.55, \mathrm{t}=5.22, \mathrm{p}<.001)$, and women with SUI (compared to women with UUI) reported better quality of life $(\beta=-.17, t=-2.02, p<.05)$ (Table 2$)$.

\section{TABLE 2 Predictors of quality of life.}

$\mathbf{R}^{2}\left(\mathbf{R}^{2} \mathrm{Aj}\right) \quad$ Models $\quad \beta \quad \mathbf{T}$

\begin{tabular}{|c|c|c|c|c|}
\hline Block 1 & & & & \\
\hline Age & $.04(.01)$ & $F(2,77)=1.57$ & -.08 & -.72 \\
\hline Type of UI & & & -.17 & -1.49 \\
\hline \multicolumn{5}{|l|}{ Block 2} \\
\hline & $.49(.46)$ & $F(5,74)=$ & .10 & 1.14 \\
\hline Age & & $14.33 * * *$ & & \\
\hline Type of UI & & & -.17 & $-.2 .02^{*}$ \\
\hline Anxiety & & & -.09 & -.84 \\
\hline Depression & & & -.11 & -1.07 \\
\hline Sexual satisfaction & & & .58 & $5.52 * * *$ \\
\hline
\end{tabular}

TABLE 1 Differences between sexual satisfaction, psychological morbidity and coping according to the severity of urine loss.

\begin{tabular}{|c|c|c|c|c|}
\hline & $\begin{array}{l}\text { Mild }(n=22) \\
\text { Mean rank }\end{array}$ & $\begin{array}{l}\text { Moderate }(n=39) \\
\text { Mean rank }\end{array}$ & $\begin{array}{l}\text { Severe }(n=19) \\
\text { Mean rank }\end{array}$ & $\chi^{2}(2)$ \\
\hline Quality of life & 57.07 & 42.23 & 17.76 & $29.61 * * *$ \\
\hline Sexual satisfaction & 48.64 & 41.49 & 29.05 & $7.39 *$ \\
\hline Anxiety & 34.48 & 42.13 & 44.13 & 2.15 \\
\hline Depression & 37.77 & 41.08 & 42.47 & .47 \\
\hline \multicolumn{5}{|l|}{ Coping strategies } \\
\hline Active coping & 41.34 & 35.71 & 49.37 & 4.95 \\
\hline Seeking of emotional support & 38.48 & 39.71 & 44.47 & .83 \\
\hline Religion & 33.82 & 38.50 & 52.34 & $7.67^{*}$ \\
\hline Positive reinterpretation & 47.75 & 37.86 & 37.53 & 3.37 \\
\hline Self-blame & 30.66 & 42.62 & 47.55 & $6.81 *$ \\
\hline Acceptance & 43.59 & 41.44 & 35.00 & 1.84 \\
\hline Expression of feelings & 38.39 & 35.76 & 52.68 & $7.57^{*}$ \\
\hline Humor & 46.16 & 36.08 & 43.03 & 3.43 \\
\hline Behavioral disengagement & 31.70 & 44.83 & 41.79 & 5.24 \\
\hline Denial & 30.09 & 38.60 & 56.45 & $14.62 * *$ \\
\hline Distraction & 28.55 & 39.83 & 55.71 & $15.60 * * *$ \\
\hline Substance use & 37.50 & 42.68 & 39.50 & 3.57 \\
\hline
\end{tabular}

Note: ${ }^{* * *} \mathrm{p}<.001 ;{ }^{* *} \mathrm{p}<.01 ;{ }^{*} \mathrm{p}<.05$ 


\section{Coping strategies as predictors of quality of life}

Less denial $(\beta=-.51, t=-4.43, p<.001)$, less distraction $(\beta=$ $\left.-.22, \mathrm{t}=-2.08, \mathrm{p}^{<.05}\right)$ and less use of religion $(\beta=-.17, \mathrm{t}=$ $-2.03, \mathrm{p}<.05)$ predicted better quality of life. The regression model explained $54 \%$ of the variance $(\mathrm{F}(5,74)=17.36$; $\mathrm{p}^{<.001)}$ (Table 3).

\section{TABLE 3 Coping strategies as predictors of quality} of life.

\begin{tabular}{lllll} 
& $\mathbf{R}^{2}\left(\mathbf{R}^{2} \mathbf{A}\right)$ & $\mathbf{F}(\mathbf{5 , 7 4 )}$ & $\beta$ & $\mathbf{t}$ \\
\hline Denial & $.54(.51)$ & $17.36^{* * *}$ & -.51 & $-4.43^{* * *}$ \\
\hline Distraction & & & -.22 & $-2.08^{*}$ \\
\hline Self-blame & & -.06 & -.54 \\
\hline $\begin{array}{l}\text { Expression of } \\
\text { feelings }\end{array}$ & & -.07 & .74 \\
\hline Religion & & & \\
\hline Note: ${ }^{* *} p^{*}<001 ;{ }^{*}<.05$ & & -.17 & $-2.03^{*}$ \\
\hline
\end{tabular}

\section{Discussion}

The results are in accordance with the literature since women with severe UI report greater impairment of quality of life, ${ }^{42}$ which means that the severity of urine loss is associated with decreased quality of life,,$^{13,43}$ and women who perceive UI as mild report greater loss of urine during sexual activity. ${ }^{44}$ Studies on coping strategies in UI are few. However, the study of Koenig et al. ${ }^{45}$ found that some individuals depend strongly on religious beliefs and practices to relieve stress, maintain self-control and hope. Therefore, it comes as no surprise that the severity of UI may lead women to feelings of anxiety, irritability and a greater need for expression of emotions. In the study of Wilson ${ }^{46}$ patients used denial to reduce the distress and to better cope with situations that generated stress. According to Carver et al., ${ }^{47}$ individuals have the support of relying on different activities to distract the stressor that is interfering with well-being.

In the current study, women with UI whose sexual life was gratifying showed a better quality of life as well as women with SUI. These findings, when compared to women with UUI, are in accordance with the literature. In fact, SUI when compared to UUI, does not affect women's quality of life significantly. ${ }^{48}$ In fact, this type of UI, allows women to find other alternatives, knowing the activities that demand more loss of urine. ${ }^{49}$ Regarding sexual satisfaction, studies found that when the loss of urine occurs during sexual intercourse, it may lead to disharmony in the couple, avoidance of sexual activity, embarrassment and shame, impairing quality of life..$^{50,51}$

Results showed that less denial, distraction and use of religion were predictors of quality of life. Although to our knowledge, no study has assessed the impact of these particular coping strategies on UI, a study with chronic patients, such as HIV positive women, showed that the use of denial, as a coping strategy, was associated with lower quality of life. ${ }^{52}$ Distraction may also be non-adaptive to disease. ${ }^{53}$ Also, in patients with cystic fibrosis, high distraction was associated with a worse quality of life. ${ }^{26}$ The study of Pargament et al. ${ }^{28}$ showed that negative religious coping was associated with less quality of life as well as well-being.

\section{LIMITATIONS}

The present study has some limitations. The sample was only collected in one major central hospital. Two subscales of the brief Cope were not included in the hypothesis testing due to their low internal consistency. The instruments used were all self-report. Future research should assess social support and body image as mediators in the relationships between sexual satisfaction and quality of life, in women with UI in larger samples.

It would also be interesting, to evaluate quality of life, sexual satisfaction, psychological morbidity and coping strategies according to the type of treatment for UI: different behavioral treatments (behavioral change, pelvic muscle rehabilitation) versus surgery and pharmacological treatment and take in consideration women that did the surgery to correct their urine loss problem, but with no success, and compare them with those that never underwent surgery. Finally, it would be important to know the impact of UI on the professional and physical activities of young women, in particular.

\section{Conclusion}

The results showed that women with higher quality of life, sexual satisfaction and less use of religion and selfblame as coping strategies to deal with the UI report their symptoms of urine loss as mild or moderate, while women with SUI, report high sexual satisfaction and less use of denial, distraction, and use of religion (coping strategies) and higher quality of life. Therefore, intervention on health promotion with these women should include their partners, since sexual satisfaction is affected, in order to help the couple to better cope with the UI.

Health professionals should also be alert by how much the UI is affecting the patient's quality of life and provide emotional support, breaking the stigma associated with loss of urine and control. When necessary, health professionals should refer these women for couple's therapy so they can get better adjusted and develop effective coping strategies to deal with urinary incontinence and their impact on the couple's intimacy. 


\section{Resumo}

Qualidade de vida em mulheres com incontinência urinária.

O objetivo deste estudo foi analisar a relação entre variáveis clínicas, psicológicas, sociodemográficas e de qualidade de vida em mulheres com incontinência urinária. A amostra foi composta de 80 mulheres com diagnóstico de incontinência urinária (IU), seguido em um Hospital Central do Norte de Portugal. As participantes responderam: Incontinence Quality of Life (I-QOL); Satisfaction with Sexual Relationship Questionnaire (SSRQ); Hospital Anxiety and Depression Scales (HADS) e o Brief Cope. Os resultados revelaram que as mulheres com uma maior qualidade de vida consideraram seus sintomas de perda de urina como leves ou moderados, em comparação àquelas com perda de urina grave. A perda de urina menos grave foi associada à maior satisfação sexual e menos uso de religião e autoculpabilização como estratégias de enfrentamento. Em termos de enfrentamento, as mulheres que consideraram a perda de urina como grave expressaram mais sentimentos em relação à IU. Incontinência urinária de esforço, alta satisfação sexual e menos uso da negação, distração e religião, como estratégias de enfrentamento, previram maior qualidade de vida. De acordo com os resultados, a IU tem um impacto na satisfação e na qualidade de vida sexual das mulheres. Assim, os programas de intervenção devem visar a essas mulheres, incluindo seus parceiros, ajudando-as a adaptar-se à sua condição e ensinar-lhes estratégias eficazes de enfrentamento, a fim de melhorar sua satisfação sexual e qualidade de vida.

Palavras-chave: incontinência urinária, qualidade de vida, satisfação sexual, morbidade psicológica, estratégias de enfrentamento.

\section{References}

1. Lee JJ. The impact of urinary incontinence levels on the social lives of older Chinese in Hong Kong. Hallym Int J Aging.2005;7(1):63-80.

2. Gotoh M. Quality of life assessment for patients with urinary incontinence. Nagoya J Med Sci. 2007;69(3-4):123-31.

3. Abrams P, Cardozo L, Fall M, Griffiths D, Rosier P, Ulmsten U, et al. The standardization of terminology of lower urinary tract function: report from the standardization sub-committee of the international continence society. Neurourol Urodyn. 2002;21(2):167-78.

4. Corcos J, Beaulieu S, Donovan J, Naughton M, Gotoh M. (2002). Quality assessment in men and women with urinary incontinence. J Urol. 2002;168(3):896-905.

5. Lopes MHBM, Higa R. Restrições causadas pela incontinência urinária à vida da mulher. Rev Esc Enferm USP. 2006;40(1):34-41.

6. Aslan G, Köseoğlu H, Sadik Ã, Gimen S, Cihan A, Esen A. Sexual function in women with urinary incontinence. Int J Impot Res. 2005;17(3):248-51.

7. Virkud A. Management of stress urinary incontinence. Best Pract Res Clin Obstet Gynaecol. 2011;25(2):205-16.
8. Kelleher C. Quality of life and urinary incontinence. Baillières Clin Obstet Gynaecol. 2000;14(2):363-79.

9. Saleh N, Bener A, Khenyab N, Al-Mansori Z, Muraikhi AA. Prevalence, awareness and determinants of health care-seeking behavior for urinary incontinence in Qatari women: a neglected problem? Maturitas. 2005;50(1):58-65.

10. Roe B, May C. Incontinence and sexuality: findings from a qualitative perspective. J Adv Nur. 1999;30(3):573-9.

11. The WHOQOL Group (1995). The world health organization quality of life assessment (WHOQOL): position paper from the World Health Organization. Soc Sci Med. 1995;41(10):1403-9.

12. Temml C, Haidinger G, Scmidbauer J, Schatzl G, Madersbacher S. Urinary Incontinence in both sexes: prevalence rates and impact on quality of life and sexual life. Neurourol Urodynam. 2000;19(3):259-71.

13. Papanicolaou S, Hunskaar S, Lose G, Sykes D. Assessment of bothersomeness and impact on quality of life of urinary incontinence in women in France, Germany, Spain and the UK. Br J Urol Int. 2005;96(6):831-8.

14. Santos P, Mendonça D, Alves O, Barbosa AM. Prevalência e impacto da incontinência urinária de stresse: antes e durante a gravidez. Acta Med Port. 2006;19(3):349-56.

15. Xu Y, Song Y, Huang $\mathrm{H}$. Impact of the tension-free vaginal tape obturator procedure on sexual function in women with stress urinary incontinence. Int J Gynecol Obstet. 2011;112(2):187-9.

16. Dalpiaz O, Kerschbaumer A, Mitterberger M, Pinggera M, Colleselli D, Bartsch G, et al. (2008). Female sexual dysfunction: a new urogynaecological research field. Br J Urol Int. 2008;101(6):717-21.

17. Auge AP, Zucchi CM, Costa FMP, Nunes K, Cunha LPM, Silva PVF, et al. Comparações entre os índices de qualidade de vida em mulheres com incontinência urinária submetidas ou não ao tratamento cirúrgico. Rev Bras Ginecol Obstet. 2006;28(6):352-7.

18. Lagro-Janssen T, Smits A, Weel CV. Urinary incontinence in women and the effect on their lives. Scand J Prim Health Care. 1992;10(3):211-6.

19. Stach-Lempinen BSS, Hakala AL, Laippala P, Lehtinen K, Metsanoja R, Kujansuu E. (2003). Severe depression determines quality of life in urinary incontinent women. Neurourol Urodynam. 2003;22(6):563-8.

20. Yip SK, Cardozo L. Psychological morbidity and female urinary incontinence. Best Pract Res Clin Obstet Gynaecol. 2007;21(2):321-9.

21. Melville JL, Walker E, Katon W, Lentz G, Miller J, Fenner D. Prevalence of comorbid psychiatric illness and its impact on symptom perception, quality of life, and functional status in women with urinary incontinence. Am J Obstet Gynecol. 2002;187(1):80-7.

22. Vigod SN, Stewart DE. Major depression in female urinary incontinence. Psychosomatics. 2006;47(2):147-51.

23. Peake S, Manderson L. The constraints of a normal life: The management of urinary incontinence by middle aged women. Women Health. 2003;37(3):37-51

24. Brittain KR, Shaw $\mathrm{C}$. The social consequences of living with and dealing with incontinence - a carers perspective. Soc Sci Med. 2007;65(6):1274-83.

25. Taylor JL, Smith PJ, Babyak MA, Barbour KA, Hoffman BM, Sebring D, et al. Coping and quality of life in patients awaiting lung transplantation. J Psychosom Res. 2008;65(1):71-9.

26. Abbott J, Hart A, Morton A, Gee L, Conway S. Health-related quality of life in adults with cystic fibrosis: the role of coping. J Psychosom Res. 2008;64(2):149-57.

27. Stanton AL, Danoff-Burg S, Cameron CL, Bishop M, Collins CA, Twillman $\mathrm{R}$, et al. Emotionally expressive coping predicts psychological and physical adjustment to breast cancer. J Consult Clin Psychol. 2000;68(5):875-82.

28. Pargament K, Smith B, Koenig H, Perez L. Patterns of positive and negative religious coping with major life stressors. J Sci Study Relig. 1998; 37(4):710-24.

29. Barbosa JMM. Avaliação da qualidade de vida e das estratégias de enfrentamento em idosos com incontinência fecal [dissertação]. Belo Horizonte: Escola de Educação Física, Fisioterapia e Terapia Ocupacional, Universidade Federal de Minas Gerais; 2006. Available at: http://www.eef. ufmg.br/mreab/documentos_new/Dissertpdf/julianamachado.pdf.

30. Klein DM, Turvey CL, Pies CJ. Relationship of coping styles with quality of life and depressive symptoms in older heart failure patients. J Aging Health. 2005;19(1):22-38.

31. Livneh H. Psychosocial adaptation to chronic illness and disability: A conceptual Framework. Rehab Couns Bull. 2001;44(3):151-60. 
32. Livneh H, Antonak RF. Psychosocial adaptation to chronic illness and disability: A primer for counselors. J Couns Dev. 2005;83(1):12-20.

33. Patrick DL, Martin ML, Bushnell DM, Yalcin I, Wagner TH, Buesching DP. Quality of life of women with urinary incontinence: further development of the incontinence quality of life instrument (I-QOL).Urology. 1999;53(1):71-6.

34. Cappelleri JC, Althof SE, Siegel RL, Shpilsky A, Bell SS, Duttagupta S. Development and validation of the self-esteem and relationship (SEAR) questionnaire in erectile dysfunction. Int J Impot Res. 2004;16(1):30-8.

35. Pais-Ribeiro JL, Raimundo A. Estudo de adaptação do questionário de satisfação com o relacionamento sexual (QSRS) em mulheres com incontinência urinária. Psicol Saúde Doenças. 2005;6(2):191-202.

36. Zigmond A, Snaith R. The hospital anxiety and depression scale. Acta Psychiatr Scand. 1983;67(6):361-70.

37. Pais-Ribeiro J, Silva I, Ferreira T, Martins A, Meneses R, Baltar M. Validation study of a Portuguese version of the hospital anxiety and depression scale. Psychol Health Med. 2007;12(2):225-37.

38. Snaith RP. The hospital anxiety and depression scale. Health Quality Life Outcomes. 2003;1(29):1-4

39. Carver CS. You want to measure coping but your protocol's too long: Consider the brief COPE. Int J Behav Med. 1997;4(1):92-100.

40. Pais-Ribeiro JL, Rodrigues AP. Questões acerca do coping: a propósito do estudo de adaptação do brief COPE. Psicol Saúde Doenças. 2004;5(1):3-15.

41. Pestana MH, Gageiro JN. Análise de dados para ciências sociais: a complementaridade do SPSS. $3^{\text {a }}$ ed. Lisboa: Edições Sílabo; 2003.

42. Di Gangi Herms AMR, Pinggera GM, de Jonge P, Strasser H, Söllner W Assessing health care needs and clinical outcome with urological case complexity: a study using INTERMED. Psychosomatics. 2003;44(3):196203
43. Minassian VA, Drutz HP, Al-Badr A. Urinary incontinence as a worldwide problem. Int J Gynecol Obstet. 2003;82(3):327-38.

44. Nygaard I, Milburn A. Urinary incontinence during sexual activity: prevalence in a gynecologic practice. J Women Health. 1995;4(1):83-6.

45. Koenig HG, Larson DB, Larson SS. Religion and coping with serious medical illness. Ann Pharmacother. 2001;35(3):352-9.

46. Wilson JF. Behavioral preparation for surgery: benefit or harm? J Behav Med 1981;4(1):79-102

47. Carver CS, Weintraub JK, Scheier MF. Assessing coping strategies: a theoretically based approach. J Pers Soc Psychol. 1989;56(2):267-83.

48. Vaart VD, Leeuw D, Roovers JP, Heintz AP. The effect of urinary incontinence and overactive bladder symptoms on quality of life in young women. $\mathrm{Br} \mathrm{J}$ Urol Int. 2002;90(6):544-9.

49. Coyne KS, Sexton CC, Irwin DE, Kopp ZS, Kelleher CJ, Milsom I. The impact of overactive bladder incontinence and other lower urinary tract symptoms on quality of life, work productivity, sexuality and emotional well-being in men and women: results from the EPIC study. Br J Urol Int. 2008;101(11):1388-95

50. Meade-D'Alisera P, Merriweather T, Wentland M, Fatal M, Ghafar M Depressive symptoms in women with urinary incontinence: a prospective study. Urol Nurs. 2001;21(6):397-9.

51. Vella M, Cardozo L. Incontinence during sexual intercourse. Womens Health Med. 2005;2(6):42-3.

52. Weaver KE, Antoni MH, Lechner SC, Durán REF, Penedo F, Fernandez MI, et al. Perceived stress mediates the effects of coping on the quality of life HIV-positive women on highly active antiretroviral therapy. AIDS Behav. 2004;8(2):175-83

53. Van den Akker OBA. Coping, quality of life and psychological symptoms in three groups of sub-fertile women. Patient Educ Couns. 2005;57(1):183-9. 